Article

\title{
Effects of Post-Emergence Herbicides and Period of Johnsongrass (Sorghum halepense (L.) Pers.) Control on Growth and Yield of Sunflower Crops
}

\author{
Anestis Karkanis*(D), Dimitrios Nakopoulos, Charikleia Palamioti, Kyriakos D. Giannoulis, Thomas Palamiotis, \\ Georgios Igoumenos, Spyridon Souipas, Vasiliki Liava and Nicholaos G. Danalatos
}

Citation: Karkanis, A.; Nakopoulos, D.; Palamioti, C.; Giannoulis, K.D.;

Palamiotis, T.; Igoumenos, G.;

Souipas, S.; Liava, V.; Danalatos, N.G. Effects of Post-Emergence Herbicides and Period of Johnsongrass (Sorghum halepense (L.) Pers.) Control on Growth and Yield of Sunflower Crops. Agronomy 2022, 12, 581. https://doi.org/10.3390/ agronomy12030581

Academic Editor: David Clements

Received: 30 December 2021 Accepted: 24 February 2022 Published: 26 February 2022

Publisher's Note: MDPI stays neutral with regard to jurisdictional claims in published maps and institutional affiliations.

Copyright: (C) 2022 by the authors. Licensee MDPI, Basel, Switzerland. This article is an open access article distributed under the terms and conditions of the Creative Commons Attribution (CC BY) license (https:// creativecommons.org/licenses/by/ $4.0 /)$.
Department of Agriculture Crop Production and Rural Environment, University of Thessaly, Fytokou St., 38446 Volos, Greece; dnakopoulos@uth.gr (D.N.); klairipalamioti2@gmail.com (C.P.); kyriakos.giannoulis@gmail.com (K.D.G.); thomaspalamiotis10@gmail.com (T.P.); g.igoumenos@gmail.com (G.I.); souipas@uth.gr (S.S.); vasiliki.liava@gmail.com (V.L.); danal@uth.gr (N.G.D.)

* Correspondence: akarkanis@uth.gr; Tel.: +30-24210-93135

\begin{abstract}
Sunflower is an important industrial crop since it is grown all over the world for oil production, while Johnsongrass (Sorghum halepense (L.) Pers.) is characterized by great competitiveness and can severely impair plant growth and crop productivity. Thus, a two-year field experiment was conducted to evaluate the impact of Johnsongrass control practices on plant growth, seed yield, and oil content of sunflower crop. The results indicated that Johnsongrass competition negatively affected sunflower growth and productivity as the lowest values of height, dry biomass, seed, and oil yields were recorded at the weed-infested treatment, followed by the weed infested for 30 days after sowing. All the other treatments had a positive effect on vegetative and yield parameters. Moreover, fluazifop-p-butyl, quizalofop-p-ethyl, and the combination of fluazifop-p-butyl and imazamox effectively controlled Johnsongrass. Specifically, in 2020, the lowest dry weight of Johnsongrass was observed in the plots where fluazifop-p-butyl + imazamox were applied. Thus, the results of this study clearly showed that the use of the above-mentioned herbicides can improve the seed and oil yield of a sunflower crop by managing Johnsongrass, while the competition of this rapidly growing weed for a short period of 30 days can significantly reduce crop yield.
\end{abstract}

Keywords: clear field technology; competitive ability; fluazifop-p-butyl; imazamox; perennial weed; quizalofop-p-ethyl

\section{Introduction}

Sunflower (Helianthus annuus L.) is an important industrial plant grown for oil production. The oil is rich in linoleic acid (55-70\%) and it is mainly used for human consumption [1-3] or biofuel production [4,5]. This plant species is cultivated on a huge scale over the world, according to the FAOSTAT database, with roughly 27.37 million hectares cultivated in 2019 and a total seed production of 56.07 million tons [6]. In Greece, sunflower was cultivated on 100,720 hectares in 2019 , with a total output of 298,960 tons [6], while the mean seed yield per hectare was about $69 \%$ higher than the global amount. The above quantitative data highlight the importance of this crop for Greek and/or worldwide agriculture.

Weeds are one of the most significant limiting factors affecting the sunflower crop's development. According to several studies, various grass and broad-leaved weeds, as well as the parasitic weed broomrape (Orobanche cumana Wallr.), significantly reduce the seed yield of this crop [3,7-9]. Weed control in this broadleaved crop is accomplished by cultural practices (e.g., competitive cultivars, mulching, and intercropping) $[10,11]$ and the use of various pre- and post-emergence herbicides [12-14]. In this crop, the development of sunflower hybrids resistant to imidazolinones (Clearfield ${ }^{\circledR}$ technology) and sulfonylureas (ExpressSun ${ }^{\circledR}$ technology) has significantly contributed to weed control by 
the application of herbicides that inhibit the enzyme acetolactate synthase, like imazamox and tribenuron-methyl [9,15-17]. Specifically, imazamox is applied for the control of grass and broadleaved weeds [9], while tribenuron-methyl is effective only against broadleaved weeds [18]. Herbicides help to suppress weeds and increase the seed yield of sunflower. Jat and Giri [19] reported that the pre-emergence application of pendimethalin increased sunflower's seed yield by $56.4 \%$ compared with the weedy control.

The perennial weed Johnsongrass (Sorghum halepense (L.) Pers.) is one of the most common grass weeds that has a negative impact on sunflower and other crops. According to previous research, rhizomatous Johnsongrass has a high competitive capacity, as competing with this weed for 55 days after sowing reduced maize seed yield by 58-72\% [20]. Such results illustrate the importance of timely control of this weed species. In broadleaved crops such as cotton, tomato, soybean, and sunflower, this weed is mainly controlled by post-emergence herbicides such as fluazifop-p-butyl, quizalofop-p-ethyl, propaguizafop, cycloxydim, and clethodim belonging to aryloxyphenoxypropionate (FOPs) and cyclohexanedione (DIMs) groups [21-24]. However, in some countries, there are confirmed Johnsongrass populations with resistance to these herbicides [21,22]. For the above-mentioned reasons, it is crucial to optimize the control of this weed. Thus, the objectives of this study were: (1) to assess the impact of Johnsongrass on sunflower growth, yield, and quality under various control treatments, (2) to evaluate Johnsongrass control with the herbicides fluazifop-p-butyl, quizalofop-p-ethyl, and fluazifop-p-butyl + imazamox, and (3) to examine the regrowth of Johnsongrass in various control treatments.

\section{Materials and Methods}

\subsection{Plant Material, Growing Conditions, and Experimental Design}

This experiment was carried out in a field with a large infestation of rhizomatous Johnsongrass at the farm of the Department of Agriculture Crop Production and Rural Environment of the University of Thessaly (Velestino, Thessaly region, Greece). This population of Johnsongrass has not been shown resistance to herbicides (e.g., FOPs or DIMs) in field trials. The soil texture was sandy clay loam (sand $38 \%$, silt $36 \%$, and clay $26 \%$ ) with a $\mathrm{pH}$ of 7.4 (1:1 soil to water ratio). The sunflower Clearfield hybrid P64LC108 with resistance to herbicide imazamox was grown during two successive years in 2019 and 2020, while the preceding crop in 2018 was maize (Zea mays L.). In 2019, the mean monthly air temperatures for April, May, June, July, and August were 13.8, 19.4, 25.8, 26.6, and $27.0{ }^{\circ} \mathrm{C}$, respectively, while in 2020 , the temperatures for April, May, June, July, and August were $13.9,20.1,21.1,26.8$, and $26.7^{\circ} \mathrm{C}$, respectively. Moreover, the total precipitation during this period was $108.2 \mathrm{~mm}$ and $106.9 \mathrm{~mm}$ in 2019 and 2020, respectively.

Sunflower was planted using a pneumatic sowing machine. The sowing took place on 22 April 2019 and 30 April 2020. The rows were $0.75 \mathrm{~m}$ apart, with $0.20 \mathrm{~m}$ between plants in each row, and the plots were $3 \mathrm{~m} \times 5 \mathrm{~m}$ in size $\left(15 \mathrm{~m}^{2}\right)$. Regarding the fertilization, prior to sowing, the inorganic fertilizer 11-15-15 was applied at a rate of $500 \mathrm{~kg} \mathrm{ha}^{-1}(55,75$, and $75 \mathrm{~kg} \mathrm{~N}, \mathrm{P}_{2} \mathrm{O}_{5}$, and $\mathrm{K}_{2} \mathrm{O}$ per ha, respectively) throughout the field, while in the middle of June the fertilizer 34.5-0-0 (ammonium nitrate) was applied at an amount of $250 \mathrm{~kg} \mathrm{ha}^{-1}$ $\left(86.25 \mathrm{~kg} \mathrm{~N} \mathrm{ha}^{-1}\right)$ with a drip irrigation system.

This experiment was performed based on a randomized complete block design with three replications, while the treatments were as follows: (1) weed free, (2) weed free for 30 days after sunflower sowing (DAS), (3) weed infested, (4) weed infested for 30 DAS, (5) fluazifop-p-butyl (Fusilade 12.5 EC, Syngenta Hellas A.E.B.E.) applied at $0.312 \mathrm{~kg}$ a.i. ha ${ }^{-1},(6)$, quizalofop-p-ethyl (Targa 5 EC, K\&N Efthymiadis A.B.E.E.) applied at $0.075 \mathrm{~kg}$ a.i. ha ${ }^{-1}$, and (7) fluazifop-p-butyl and imazamox (Pulsar 4 SL, BASF Hellas A.B.E.E.). For herbicides mixture, imazamox was applied at $0.04 \mathrm{~kg}$ a.i. ha ${ }^{-1}$, while fluazifop-p-butyl was applied at $0.187 \mathrm{~kg}$ a.i. ha ${ }^{-1}$ (growing season 2020) or $0.250 \mathrm{~kg}$ a.i. $\mathrm{ha}^{-1}$ (growing season 2019). In 2020, a lower dose of fluazifop-p-butyl was applied as in 2019 , intense phytotoxicity symptoms were observed on sunflower plants in the mixture with imazamox. Moreover, for herbicides mixture, the adjuvant Dash ${ }^{\circledR} \mathrm{HC}$ (fatty acid 
esters: $37.5 \% w / v$, oleic acid: $5 \% w / v$, phosphate esters: $22.5 \% w / v)$ was added at an amount of $500 \mathrm{~mL} \mathrm{ha}^{-1}$. In both experimental years, the treatments were applied in the same plots, while the post-emergence application of herbicides was made at 4 to 6 leaf stage of sunflower plants (23 and 20 DAS in 2019 and 2020, respectively) using a field plot sprayer (spray volume of $300 \mathrm{~L} \mathrm{ha}^{-1}$, pressure $250 \mathrm{kPa}$, and flat fan nozzles). In the weed free for 30 DAS plots, three hand hoeing's were made at 10, 20, and 30 DAS, while in the weed infested for 30 DAS plots, four hand hoeing's were made at 30, 40, 50, and 60 DAS. Finally, in the weed free plots, six hand hoeing's were made at 10, 20, 30, 40, 50, and 60 DAS. Thereafter, no hand hoeing was done due to the great height of sunflower plants.

\subsection{Sampling, Measurements and Methods}

\subsubsection{Field Measurements}

Sunflower

To evaluate the effects of Johnsongrass on sunflower crop under various management practices, sunflower characteristics (e.g., plant height, aboveground biomass, SPAD readings, seed yield, 1000-seed weight, and head weight) were measured. Height measurement was performed on five sunflower plants per treatment, while for the quantification of the crop aboveground biomass, three plants per experimental plot were cut and dried in an oven at $70{ }^{\circ} \mathrm{C}$ until the plant tissues were fully dried. The SPAD-502 chlorophyll meter (Konica Minolta Optics, Inc., Osaka, Japan) was used for the determination of relative chlorophyll content (SPAD readings). This physiological parameter was determined on five sunflower plants in each experimental plot. SPAD values, height, and aboveground biomass were measured periodically during the growing season $(37,50$, and 83 DAS in $2019 ; 35,52$, and 81 DAS in 2020).

Finally, for the determination of seed yield and its components (1000-seed weight and head weight), five sunflower heads were manually harvested when the seed moisture was about 10\%, on 4 September 2019 and 1 September 2020. After the sunflower threshing, four samples of 100 seeds were weighed for each treatment to determine the 1000-seed weight.

\section{Johnsongrass}

The estimation of Johnsongrass biomass was carried out periodically $(37,50$, and 83 DAS in 2019; 35, 52, and 81 DAS in 2020) on an area of 1 square meter in each experimental plot. After cutting the stems of Johnsongrass plants', the samples were dried in an oven at $70{ }^{\circ} \mathrm{C}$ until the plant tissues were fully dried. Finally, the density of Johnsongrass was estimated at 83 and 81 DAS in 2019 and 2020, respectively.

\subsubsection{Oil Content and Yield Determination}

The estimation of oil content in the harvested seeds of sunflower was occurred using the DA 7250 NIR (near-infrared reflectance) analyzer (Perten Instruments, Hägersten, Sweden), while the oil yield was determined using the following Equation (1):

$$
\text { Oil yield }\left(\mathrm{kg} \mathrm{ha}^{-1}\right)=\text { seed yield }\left(\mathrm{kg} \mathrm{ha}^{-1}\right) \times \text { oil content }(\%)
$$

\subsubsection{Statistical Analysis}

The data for all the measured features (e.g., sunflower: plant's height, aboveground biomass, SPAD readings, seed yield, oil content, and oil yield; Johnsongrass: dry biomass) were statistically analyzed with SigmaPlot 12.0 software (Systat Software, San Jose, CA, USA). Primarily, analysis of variance (ANOVA) was performed and then the Fisher's Least Significant Difference (LSD) test $(p=0.05)$ was used to separate means of the seven experimental treatments (weed free, weed free for 30 DAS, weed infested, weed infested for 30 DAS, fluazifop-p-butyl, quizalofop-p-ethyl, and fluazifop-p-butyl + imazamox). For all measured parameters, the normality test (Shapiro-Wilk) and equal variance test were satisfied. 


\section{Results}

\subsection{Johnsongrass Dry Biomass and Density}

In 2019, the herbicides exhibited high efficacy against Johnsongrass (Figure 1). For instance, at 83 DAS, the application of fluazifop-p-butyl decreased the dry weight of Johnsongrass by $90 \%$ compared with the weed-infested treatment. In the second year of the experiment, the infestation of Johnsongrass was more intense at the weed-infested treatment, as the dry weight reached $4636.4 \mathrm{~kg} \mathrm{ha}^{-1}$ at 81 DAS. However, the herbicides provided high control efficacy against Johnsongrass. The lowest value $\left(7.7 \mathrm{~kg} \mathrm{ha}^{-1}\right)$ was observed in the combination of fluazifop-p-butyl with imazamox and dry weight was declined by $99.8 \%$ compared with the weed-infested treatment. Similar results were recorded for Johnsongrass density (Figure 2). In both years, at 83 and 81 DAS, the highest density of this weed was recorded in the weed-infested treatment (176.0 and 151.1 stems $\mathrm{m}^{-2}$ for the first and second growing season, respectively).
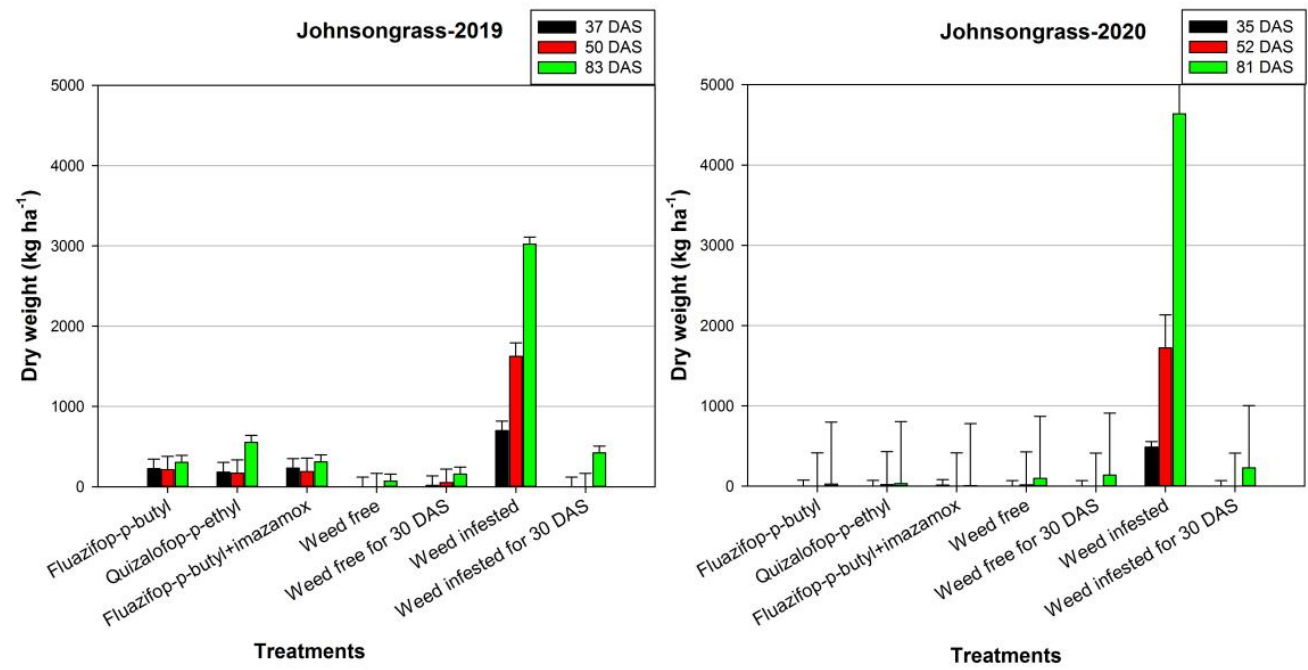

Figure 1. Effects of various control treatments on Johnsongrass dry biomass $\left(\mathrm{kg} \mathrm{ha}^{-1}\right)$ at different days after sowing (DAS), in 2019 and 2020. For each sampling date, error bars indicate the LSD $_{5 \%}$ value.

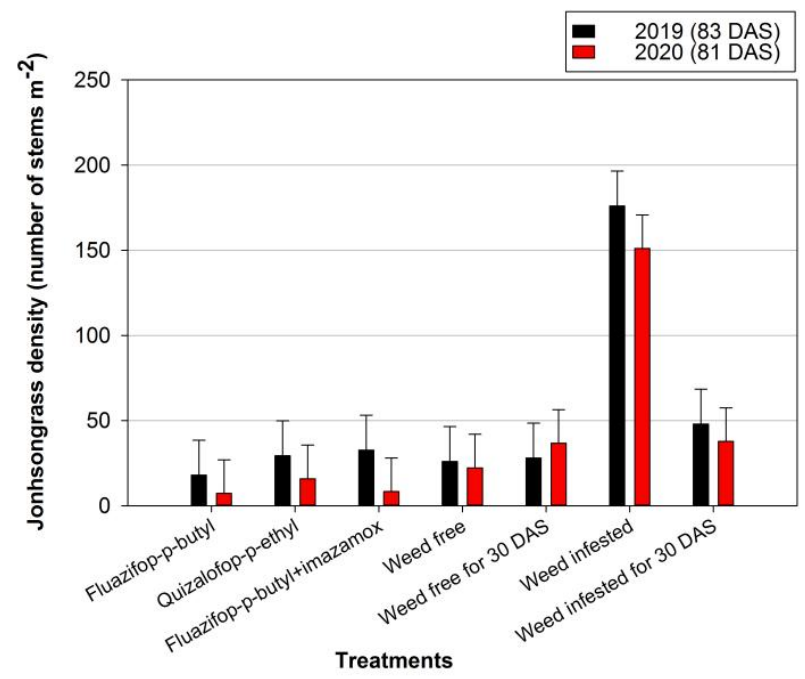

Figure 2. Effects of various control treatments on Johnsongrass density (number of stems $\mathrm{m}^{-2}$ ) at 81 and 83 days after sowing (DAS), in 2019 and 2020, respectively. For each sampling date, error bars indicate the $\mathrm{LSD}_{5 \%}$ value. 


\subsection{Sunflower Growth Parameters and Chlorophyll Content}

The herbicides fluazifop-p-butyl and quazilofop-p-ethyl caused slight chlorosis in leaves. In addition, the mixture of fluazifop-p-butyl with imazamox caused small necrosis on the youngest developing leaves, while the chlorosis was more intense than that observed in the other herbicide treatments. The phytotoxicity symptoms of fluazifop-p-butyl were observed only in 2019. In the second growing period, a lower dose of the herbicide fluazifopp-butyl was applied in the treatment fluazifop-p-butyl + imazamox and the chlorosis was not so intense. In all herbicide treatments, the symptoms were transient.

Herbicides had a negative influence on the height of sunflower plants in 2019 at 37 DAS as the greatest height $(46.5$ and $46.3 \mathrm{~cm}$ ) was recorded at the weed free and weed free for 30 DAS treatments (Figure 3). However, in 2020, there were no significant differences between the foregoing treatments and fluazifop-p-butyl or quizalofop-p-ethyl at the first measurement. In 2019, at 50 DAS, the application of quizalofop-p-ethyl and fluazifop-pbutyl + imazamox led to decreased height compared with fluazifop-p-butyl, weed free, and weed free for 30 DAS treatments. In contrast, in 2020, at 52 DAS assessing all the treatments, there were no significant differences, except for the weed-infested treatment where the lowest height $(118.8 \mathrm{~cm})$ was recorded. In terms of final measurement, in both years, the weed-infested and weed-free treatments had the lowest and maximum heights, respectively.
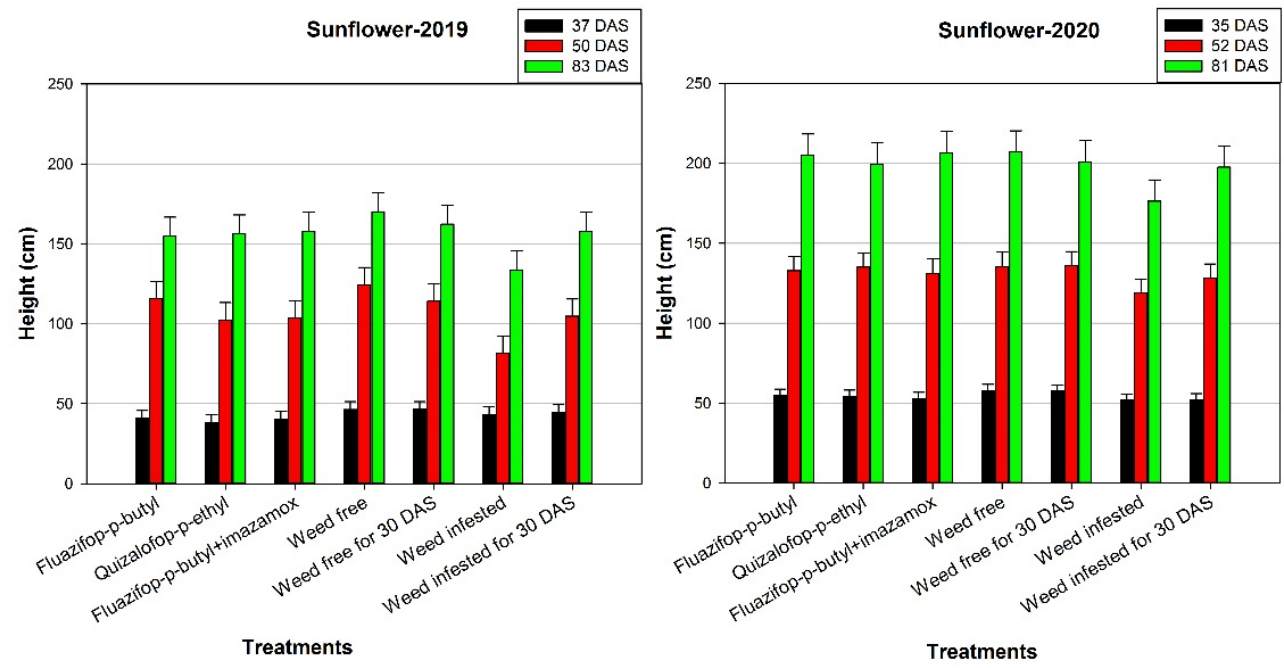

Figure 3. Effects of various control treatments of Johnsongrass on height $(\mathrm{cm})$ of sunflower plants at different days after sowing (DAS), in 2019 and 2020. For each sampling date, error bars indicate the $\mathrm{LSD}_{5} \%$ value.

Concerning the dry weight of the crop, in 2020, at 35 DAS, the weed-infested treatment had a significantly lower weight compared with the other treatments (Figure 4). Conversely, in the first growing season, at the same measurement, the application of the herbicides led to decreased dry weight in comparison with the weed-free treatment. At the second measurement, in 2020, the application of the herbicides did not have a negative effect on the dry weight of the crop, while in 2019, the application of fluazifop-p-butyl combined with imazamox led to a significant reduction in the dry weight. In both years, at 83 and 81 DAS, the highest dry weight of the plants was recorded in the weed-free treatment $(14,845.8$ and $14,234.9 \mathrm{~kg} \mathrm{ha}^{-1}$ for the first and second growing season, respectively). In general, the dry weight of the crop was greater in herbicide treatments compared with the weed-infested treatment. For instance, in fluazifop-p-butyl treatment, the dry weight was greater by up to $81 \%$ than that of the weed infested. 

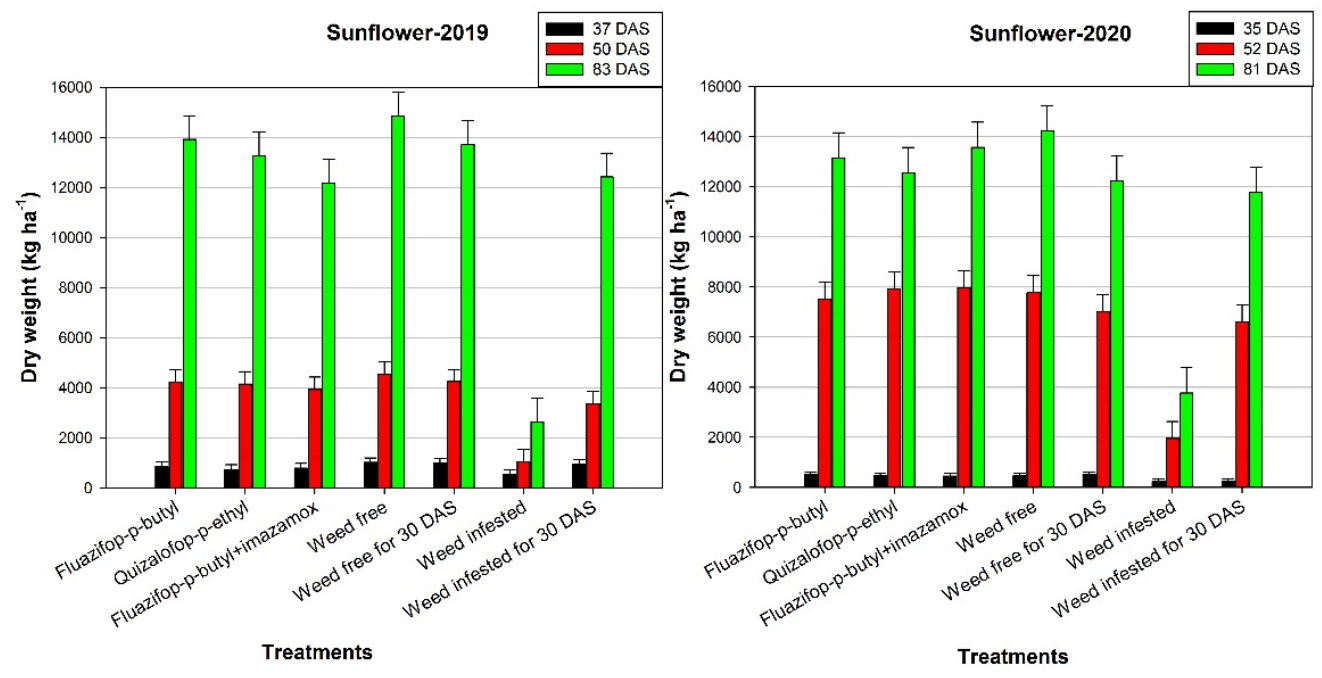

Figure 4. Effects of various control treatments of Johnsongrass on dry weight $\left(\mathrm{kg} \mathrm{ha}^{-1}\right)$ of sunflower at different days after sowing (DAS), in 2019 and 2020. For each sampling date, error bars indicate the $\mathrm{LSD}_{5 \%}$ value.

In terms of relative chlorophyll content, the weed-free plots had the greatest value in both the first and second measurements in 2019, and this treatment was significantly greater than the herbicide-treated plots (Figure 5). However, at 83 DAS, there were no differences among the treatments, except for the weed-infested plots that the SPAD value was significantly lower than the other plots. Similarly, in the second year of the experiment at 52 and 81 DAS, the relative chlorophyll content was almost stable among the treatments apart from the weed infested, as in this treatment chlorosis was observed in the sunflower plants.
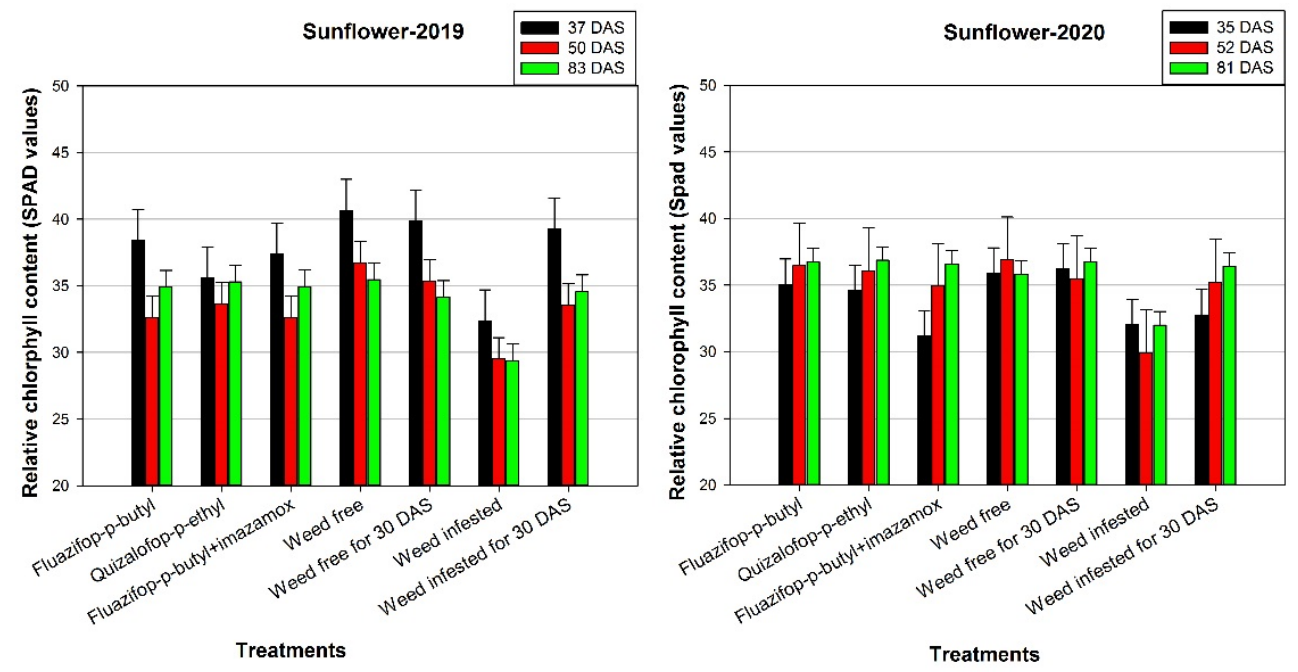

Figure 5. Effects of various control treatments of Johnsongrass on relative chlorophyll content (SPAD values) of sunflower at different days after sowing (DAS), in 2019 and 2020. For each sampling date, error bars indicate the $\mathrm{LSD}_{5 \%}$ value.

\subsection{Seed Yield and Its Parameters}

In 2019, the highest sunflower flower head weight was recorded in weed-free treatment, while there were significant differences between fluazifop-p-butyl and fluazifopp-butyl + imazamox treatments (Table 1). However, in 2020, there were no significant differences among the plots where the herbicides were applied and the weed free or weed free for 30 DAS plots. In 2019 and 2020, the application of fluazifop-p-butyl led to an 
increase of $51.05 \%$ and $48.87 \%$ compared with the weed-infested treatment, while the equivalent percentages of fluazifop-p-butyl with imazamox was $42.52 \%$ and $50.52 \%$.

Table 1. Effects of various control treatments of Johnsongrass on sunflower flower head weight (g), 1000-seed weight ( $\mathrm{g})$, and seed yield $\left(\mathrm{kg} \mathrm{ha}^{-1}\right)$ of sunflower at different days after sowing (DAS), in 2019 and 2020.

\begin{tabular}{|c|c|c|c|}
\hline $\begin{array}{l}2019 \\
\text { Treatments }\end{array}$ & Flower Head Weight (g) & 1000-Seed Weight (g) & Seed Yield $\left(\mathrm{kg} \mathrm{ha}^{-1}\right)$ \\
\hline Fluazifop-p-butyl & $128.0 \mathrm{ab}$ & $73.8 \mathrm{a}$ & $4069.8 \mathrm{ab}$ \\
\hline Quizalofop-p-ethyl & $122.5 \mathrm{~b}$ & $74.8 \mathrm{a}$ & 3901.2 bc \\
\hline Fluazifop-p-butyl + imazamox & $109.0 \mathrm{c}$ & $73.9 \mathrm{a}$ & $3458.2 \mathrm{~d}$ \\
\hline Weed free & $137.5 \mathrm{a}$ & $73.5 \mathrm{a}$ & $4248.5 \mathrm{a}$ \\
\hline Weed free for 30 DAS & $129.4 \mathrm{ab}$ & $74.1 \mathrm{a}$ & $3721.9 \mathrm{~cd}$ \\
\hline Weed infested & $62.6 \mathrm{~d}$ & $64.2 \mathrm{a}$ & $901.5 \mathrm{f}$ \\
\hline Weed infested for 30 DAS & $119.4 \mathrm{bc}$ & $74.5 \mathrm{a}$ & $3175.5 \mathrm{e}$ \\
\hline $\mathrm{LSD}_{5} \%$ & 12.45 & ns & 301.92 \\
\hline $\begin{array}{l}2020 \\
\text { Treatments }\end{array}$ & Flower Head Weight (g) & 1000-Seed Weight (g) & Seed Yield $\left(\mathrm{kg} \mathrm{ha}^{-1}\right)$ \\
\hline Fluazifop-p-butyl & $130.8 \mathrm{ab}^{1}$ & $76.1 \mathrm{a}$ & $4836.2 \mathrm{ab}$ \\
\hline Quizalofop-p-ethyl & $131.7 \mathrm{ab}$ & $77.4 \mathrm{a}$ & $4955.0 \mathrm{a}$ \\
\hline Fluazifop-p-butyl + imazamox & $135.2 \mathrm{a}$ & $76.9 \mathrm{a}$ & $4850.9 \mathrm{ab}$ \\
\hline Weed free & $137.6 \mathrm{a}$ & $78.8 \mathrm{a}$ & $5050.2 \mathrm{a}$ \\
\hline Weed free for 30 DAS & $134.7 \mathrm{a}$ & $78,1 \mathrm{a}$ & $4589.3 \mathrm{~b}$ \\
\hline Weed infested & $66.9 c$ & $67.5 \mathrm{~b}$ & $1339.9 \mathrm{~d}$ \\
\hline Weed infested for 30 DAS & $125.5 \mathrm{~b}$ & $77.1 \mathrm{a}$ & $4029.8 \mathrm{c}$ \\
\hline $\mathrm{LSD}_{5 \%}$ & 8.36 & 6.43 & 347.72 \\
\hline
\end{tabular}

${ }^{1}$ For each column, means followed by different letters indicate significant differences according to the LSD test.

The 1000-seed weight was almost stable among the treatments as in 2019, with treatments having no significant effect on this trait and in 2020, a decrease was observed only in the weed-infested plots. In general, flower head weight and 1000-seed weight were higher in the second year of the experiment and consequently, the seed yield was greater. In both years, the maximum yield (4248.5 and $5050.2 \mathrm{~kg} \mathrm{ha}^{-1}$ ) was observed in weed-free plots and there were significant differences between weed free and weed free for 30 DAS.

\subsection{Oil Content and Yield}

The weed-infested treatment had the highest oil content in both years $(50.3 \%$ and $45.9 \%$ in 2019 and 2020, respectively) and was significantly greater than the other treatments (Table 2). There were no significant differences in oil content among the herbicide treatments. In 2019, the oil content in quizalofop-p-ethyl plots was lower in comparison with weed infested for 30 DAS.

In terms of oil yield, the lowest values were found in weed-infested plots, followed by weed-infested for 30 DAS plots and weed-free plots. In 2020, the oil yields were greater in all the treatments owing to the higher seed yield that had been recorded in the second year of the experiment. Oil yield in 2019 varied from 454.4 to $1868.2 \mathrm{~kg} \mathrm{ha}^{-1}$, while it ranged from 615.0 to $2202.0 \mathrm{~kg} \mathrm{ha}^{-1}$ in 2020 . The combination of fluazifop-p-ethyl and imazamox considerably reduced oil yield in the first year of the experiment compared with the other herbicide treatments. However, in the second year of the experiment, there were no differences between the foregoing treatments. In 2020, the application of herbicides induced an increase in oil yield by up to $71.7 \%$ compared with the weed-infested treatment. 
Table 2. Effects of various control treatments of Johnsongrass on oil content (\%) and yield $\left(\mathrm{kg} \mathrm{ha}^{-1}\right)$ of sunflower at different days after sowing (DAS), in 2019 and 2020.

\begin{tabular}{lcccc}
\hline \multirow{2}{*}{ Treatments } & \multicolumn{2}{c}{ Oil Content \% } & \multicolumn{2}{c}{ Oil Yield (kg ha $^{-\mathbf{1}}$ ) } \\
\cline { 2 - 5 } & $\mathbf{2 0 1 9}$ & $\mathbf{2 0 2 0}$ & $\mathbf{2 0 1 9}$ & $\mathbf{2 0 2 0}$ \\
\hline Fluazifop-p-butyl & $44.5 \mathrm{bc}$ & $42.6 \mathrm{~b}$ & $1813.1 \mathrm{ab}$ & $2058.6 \mathrm{ab}$ \\
Quizalofop-p-ethyl & $43.0 \mathrm{c}$ & $43.8 \mathrm{~b}$ & $1678.6 \mathrm{bc}$ & $2169.5 \mathrm{a}$ \\
Fluazifop-p-butyl + imazamox & $44.7 \mathrm{bc}$ & $42.4 \mathrm{~b}$ & $1544.1 \mathrm{de}$ & $2056.2 \mathrm{ab}$ \\
Weed free & $44.0 \mathrm{bc}$ & $43.6 \mathrm{~b}$ & $1868.2 \mathrm{a}$ & $2202.0 \mathrm{a}$ \\
Weed free for 30 DAS & $43.3 \mathrm{bc}$ & $42.7 \mathrm{~b}$ & $1613.2 \mathrm{~cd}$ & $1960.0 \mathrm{~b}$ \\
Weed infested & $50.3 \mathrm{a}$ & $45.9 \mathrm{a}$ & $454.4 \mathrm{f}$ & $615.0 \mathrm{~d}$ \\
Weed infested for 30 DAS & $45.8 \mathrm{~b}$ & $42.9 \mathrm{~b}$ & $1454.8 \mathrm{e}$ & $1727.2 \mathrm{c}$ \\
\hline LSD & 2.44 & 2.03 & 167.05 & 181.94 \\
\hline
\end{tabular}

${ }^{1}$ For each column, means followed by different letters indicate significant differences according to the LSD test.

\section{Discussion}

\subsection{Herbicides Efficacy}

Our results showed that the herbicides quizalofop-p-ethyl, fluazifop-p-butyl, and fluazifop-p-butyl + imazamox exhibited high efficacy against Johnsongrass (Figure 6e). Assessing the dry biomass of Johnsongrass, there were no significant differences between the above-mentioned herbicides, while their efficacy (dry weight reduction in final measurement) against this weed was up to $90 \%$ and $99.8 \%$ in 2019 and 2020, respectively. In a recent study, Kanatas et al. [25] reported that quizalofop-p-ethyl applied at $0.15 \mathrm{~kg}$ a.i. ha ${ }^{-1}$ provided high efficacy (94.5-96.9\%) against Johnsongrass in a vineyard. Similarly, Griffin et al. [26] observed that the herbicides fluazifop $\left(0.42 \mathrm{~kg}\right.$ a.i. ha $\left.{ }^{-1}\right)$, quizalofop $\left(0.077 \mathrm{~kg}\right.$ a.i. ha $\left.{ }^{-1}\right)$, and clethodim $\left(0.28 \mathrm{~kg}\right.$ a.i. ha $\left.{ }^{-1}\right)$ showed high efficacy against this grass weed in a soybean crop (Glycine max (L.) Merr.). In contrast, in Italy, Scarabel et al. [22] found some Johnsongrass populations with resistance to FOP herbicides (e.g., fluazifop-p-butyl, quizalofop-p-ethyl, and propaquizafop).
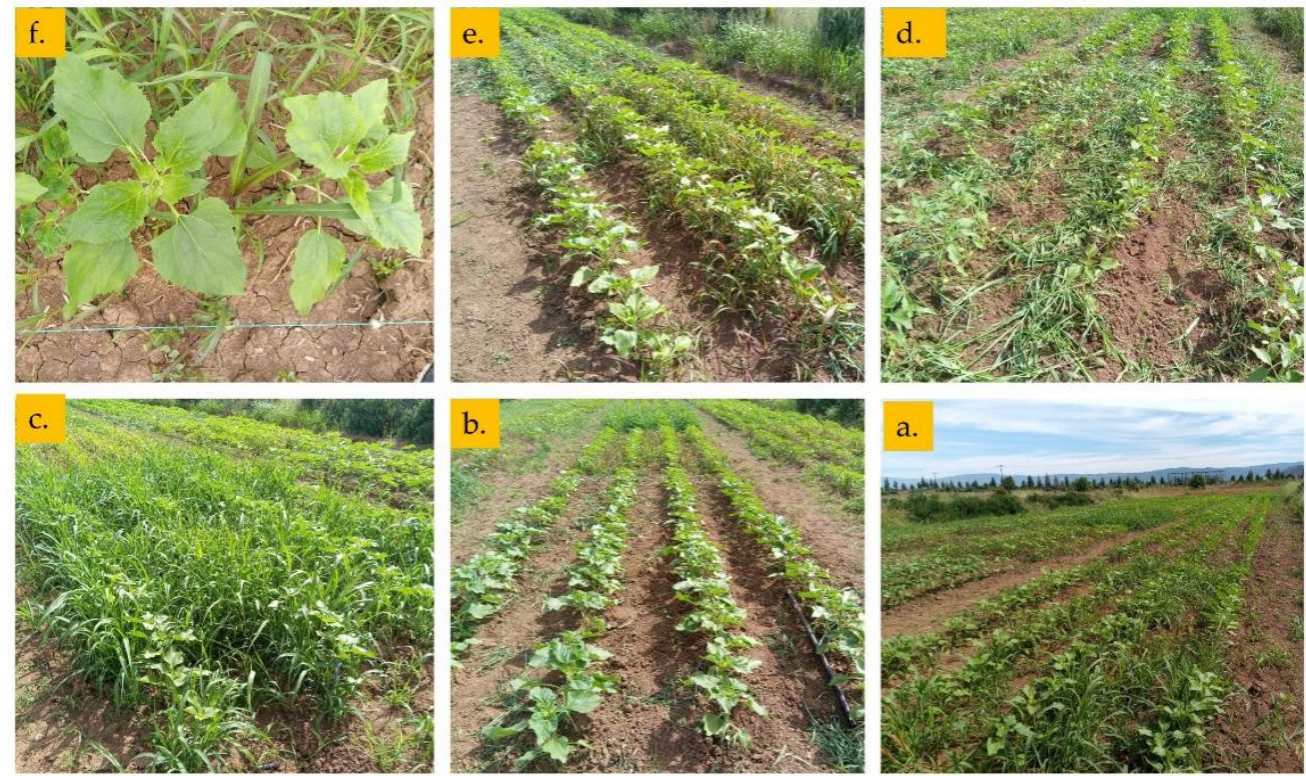

Figure 6. (a) Experimental field at 30 DAS (days after sowing) in 2019. (b) Weed free plot. (c) Weed infested plot. (d) Weed infested for 30 DAS plot. (e) Fluazifop-p-butyl plot. (f) Chlorosis on sunflower leaves at fluazifop-p-butyl.

Moreover, it is worth mentioning that the effectiveness of these herbicides was greater in 2020 compared with that in 2019. Probably, herbicides reduced the growth of John- 
songrass rhizomes in the soil at the first experimental period and thus, decreased Johnsongrass infestation during the second experimental year. The above-mentioned results are confirmed by the Johnsongrass density data, as in 2020 the number of Johnsongrass stems $\mathrm{m}^{-2}$ was lower compared to that in 2019. Finally, it is important to point out that Johnsongrass showed slight regrowth from rhizomes in plots where the herbicides were applied. For instance, in 2019, Johnsongrass dry biomass at 81-83 DAS was 1.4 to 3.3-fold greater than that at 50-52 DAS. In a field experiment conducted in a maize crop, regrowth of this weed was also observed in various nicosulfuron treatments [20].

\subsection{Sunflower Growth, Yield, and Quality}

The development of sunflower plants was negatively affected by Johnsongrass competition. In particular, during the two-year experiment, aboveground dry biomass significantly decreased in weed-infested plots compared with the other treatments. However, the plant's height was affected to a lesser extent by the Johnsongrass competition compared to the aboveground biomass. In contrast, Khan et al. [27] mentioned that the height of sunflower plants did not differ among the treatments fluazifop-p-butyl, hand weeded (once or twice), and the weedy control. Regarding the effects of herbicide application on sunflower crop, our results showed that fluazifop-p-butyl, quizalofop-p-ethyl, and fluazifop-p-butyl + imazamox positively influenced plant growth compared with that in weed-infested plots due to high Johnsongrass control. In contrast, Johnsongrass competition for the whole growing period decreased dry biomass by $82.2 \%$ and $73.6 \%$ in 2019 and 2020, respectively. The results of Karkanis et al. [20] in a maize crop are in agreement with the findings of this study, as they observed that the Johnsongrass competition caused a severe reduction $(62-80 \%)$ in dry biomass production.

The reduction in dry biomass and height of sunflower plants in weed infested, weed infested for $30 \mathrm{DAS}$, and weed free for 30 DAS plots is mainly due to the decrease in chlorophyll content in leaves. The competition of sunflower plants with Johnsongrass for nutrients (e.g., nitrogen) during the whole growing period or for $30 \mathrm{DAS}$ led to a significant reduction in the SPAD values. Similarly, Karkanis et al. [20] mentioned a decrease in chlorophyll content on maize crop that was infested by Johnsongrass. It is also important to mention that in the first growing season the herbicides fluazifop-p-butyl, quizalofop-pethyl, and fluazifop-p-butyl + imazamox slightly decreased the relative chlorophyll content from $5.57 \%$ to $12.46 \%$ at the first measurement which was made two weeks after herbicides application. However, in 2020, fluazifop-p-butyl + imazamox was the only herbicide that caused a reduction in SPAD values. This reduction was due to chlorosis caused by these herbicides. Similarly, Jursík et al. [9] and Raul et al. [24] reported that the herbicides imazamox and fluazifop-p-butyl caused chlorosis in sunflower leaves. Imidazolinone (e.g., imazamox) or sulfonylurea (e.g., tribenuron-methyl) herbicides inhibit the enzyme acetolactate synthase (ALS), and the main symptom of ALS inhibition is chlorosis of plant tissues [28]. Moreover, aryloxyphenoxypropionate herbicides (FOPs) such as fluazifop-pbutyl and quizalofop-p-ethyl inhibit the enzyme acetyl-CoA carboxylase (ACCase) and cause chlorosis in the leaf tissues [28,29]. In another study, Tichý et al. [16] reported that tribenuron-methyl caused chlorosis and leaf deformation, while the graminicide propaquizafop caused small necrosis on the youngest developing leaves. According to these authors, plant injury was more intense on the mixture of tribenuron-methyl with propaquizafop. Similarly, in our study, the phytotoxicity symptoms were more intense in the mixture of fluazifop-p-butyl and imazamox compared with fluazifop-p-butyl.

With regard to the effects of various control practices on seed yield and its components, our results indicated that the lowest values of seed yield, 1000-seed weight, and flower head weight were recorded in weed-infested treatment, while the high efficacy of herbicides fluazifop-p-butyl, quizalofop-p-ethyl, and fluazifop-p-butyl + imazamox against Johnsongrass had a beneficial effect on head weight and seed yield compared with the untreated plots. The seed yield in herbicide treatments was higher by up to $77.8 \%$ than that of the weed-infested treatment revealing the great competitiveness of Johnsongrass against 
sunflower for light, nutrients, and water. A high level of seed yield reduction $(79-86 \%)$ due to Johnsongrass competition is also reported by Karkanis et al. [20] in a maize crop. Moreover, in other studies, it has been shown that effective weed control contributes significantly to increasing sunflower yield. For instance, Panacci et al. [30] and Jursík et al. [9] both found that effective weed control with pre-emergence (e.g., S-metolaxhlor + oxyfluorfen) or post-emergence herbicides (e.g., imazamox, tribenuron-methyl, and tribenuron-methyl + propaquizafop) resulted in higher seed yields in this crop. In the first experimental year, the combination of fluazifop-p-butyl with imazamox slightly decreased the head weight and seed yield compared with the application of fluazifop-p-butyl due to the more intense chlorosis observed in sunflower leaves in the early growth stages of plants. Our results also revealed that Johnsongrass competition for 30 DAS significantly reduced both the flower head weight and seed yield, highlighting the significance of timely weed control to achieve high seed yields in this crop. The importance of timely weed control in sunflower, especially when no pre-emergence herbicides have been applied, was also mentioned by Elezovic et al. [7], while Wanjari et al. [31] reported that weed control should be made at 20 to 49 DAS.

Oil content in sunflower seeds varied significantly. Johnsongrass competition significantly increased oil accumulation in the seeds as the greatest values were recorded in the weed-infested treatment. This increase in the oil accumulation in seeds is probably due to the intense competition of Johnsongrass for water, nutrients, and light that caused a significant reduction in the size of the flower heads which was reduced by $51.4-54.5 \%$ in weed-infested plots compared with weed-free plots. Moreover, it is reported in other crops such as milk thistle (Silybum marianum (L.) Gaertn.) that under water stress conditions the oil content in seeds was increased [32]. Thus, it seems that the intense competition of Johnsongrass plants for water has contributed to the increase in the oil content in sunflower seeds. In contrast to our results, Simić et al. [33] observed that weed competition negatively affected the oil content. It is also important to point out that the oil content in seeds was higher (42.4\% to 50.3\%) than that reported by Varalakshmi et al. [34] and Baghbani-Arani et al. [35], who mentioned $39.7 \%$ and $37.7 \%$ as the maximum oil content. However, in field experiments conducted in the USA, Pabuayon et al. [36] recorded a maximum oil content of $46.8 \%$. Moreover, Johnsongrass competition for the whole growing period caused a reduction in oil yield by down to $75.7 \%$ as a result of reduced seed yield. Similarly, Hamzei et al. [37] observed that weed competition for the whole growing period resulted in oil yield reduction by $69.3 \%$ in a canola (Brassica napus L.) crop.

\section{Conclusions}

Johnsongrass showed high competitive ability against sunflower crop due to the production of high aboveground biomass. In weed-infested plots, its dry biomass was $3022.4 \mathrm{~kg} \mathrm{ha}^{-1}$ in the first experimental period, while in the second experimental period was 1.53-fold greater due to accumulated growth of rhizomes. Regarding the herbicides efficacy against this weed, our results reveal that quizalofop-p-ethyl, fluazifop-p-butyl, and fluazifop-p-butyl + imazamox showed high control rates which ranged between 81.7 to $99.8 \%$ and the highest values were recorded in 2020. In addition, the efficacy of fluazifop-pbutyl + imazamox was not statistically different than that of fluazifop-p-butyl. It is also important to point out that the mixture of fluazifop-p-butyl with imazamox caused more intense chlorosis of leaves in the early growth stages of sunflower plants compared with fluazifop-p-butyl or quizalofop-p-ethyl. Regardless of these toxicity symptoms, both the seed and oil yield were significantly greater in the mixture of the two herbicides compared with that in weed-infested treatment. A remarkable result of this study was the fact that Johnsongrass presence for only 30 DAS severely decreased crop biomass, head weight, and seed or oil yields. In conclusion, our results show the importance of timely and effective control of Johnsongrass to achieve high yields in sunflower crops.

Author Contributions: Conceptualization, A.K.; formal analysis, S.S. and A.K.; investigation, D.N., C.P., K.D.G., T.P., G.I. and A.K; methodology, S.S. and A.K.; supervision, A.K.; writing-original draft 
preparation, V.L. and A.K.; writing-review and editing, K.D.G., N.G.D. and A.K. All authors have read and agreed to the published version of the manuscript.

Funding: This research received no external funding.

Data Availability Statement: The data presented in this study are available in this article.

Conflicts of Interest: The authors declare no conflict of interest.

\section{References}

1. Salas, J.J.; Bootello, M.A.; Garcés, R. 14-Food uses of sunflower oils. In Sunflower: Chemistry, Production, Processing, and Utilization; Martínez-Force, E., Dunford, N.T., Salas, J.J., Eds.; AOCS Press: Urbana, IL, USA, 2015; pp. 441-464.

2. Premnath, A.; Narayana, M.; Ramakrishnan, C.; Kuppusamy, S.; Chockalingam, V. Mapping quantitative trait loci controlling oil content, oleic acid and linoleic acid content in sunflower (Helianthus annuus L.). Mol. Breed. 2016, 36, 106. [CrossRef]

3. Cvejić, S.; Radanović, A.; Dedić, B.; Jocković, M.; Jocić, S.; Miladinović, D. Genetic and genomic tools in sunflower breeding for broomrape resistance. Genes 2020, 11, 152. [CrossRef] [PubMed]

4. $\quad$ Portillo, E.R.; Colin, A.; Amaya, A.; Romero, R. The energy balance of biodiesel production from sunflower oil. Energy Sources A Recovery Util. Environ. Eff. 2014, 36, 2271-2280. [CrossRef]

5. Dueso, C.; Muñoz, M.; Moreno, F.; Arroyo, J.; Gil-Lalaguna, N.; Bautista, A.; Gonzalo, A.; Sánchez, J.L. Performance and emissions of a diesel engine using sunflower biodiesel with a renewable antioxidant additive from bio-oil. Fuel 2018, 234, 276-285. [CrossRef]

6. Food and Agriculture Organization of the United Nations. FAOSTAT Database. Available online: www.fao.org/faostat (accessed on 4 April 2021).

7. Elezovic, I.; Datta, A.; Vrbnicanin, S.; Glamoclija, D.; Simic, M.; Malidza, G.; Knezevic, S.Z. Yield and yield components of imidazolinone-resistant sunflower (Helianthus annuus L.) are influenced by pre-emergence herbicide and time of post-emergence weed removal. Field Crops Res. 2012, 128, 137-146. [CrossRef]

8. Hladni, N.; Dedi, B.; Jocic, S.; Miklic, V.; Dusanic, N. Evaluation of resistance of new sunflower hybrids to broomrape in the breeding programs in Novi Sad. Helia 2012, 35, 89-98. [CrossRef]

9. Jursík, M.; Fendrychová, V.; Kolářová, M.; Andr, J.; Soukup, J. Optimising Clearfield and ExpressSun sunflower technologies for Central European conditions. Plant Prot. Sci. 2017, 53, 265-272. [CrossRef]

10. Latify, S.; Yousefi, A.R.; Jamshidi, K. Integration of competitive cultivars and living mulch in sunflower (Helianthus annuus L.): A tool for organic weed control. Org. Agric. 2017, 7, 419-430. [CrossRef]

11. Kalaisudarson, S.; Srinivasaperumal, A.P.; Senthilvalavan, P.; Balakrishnan, T.; Arathi, P.V. Integrated weed management practices on weed control in sunflower (Helianthus annuus L.). Plant Arch. 2020, 20, 1550-1552.

12. Jursík, M.; Kočárek, M.; Kolářová, M.; Tichý, L. Effect of different soil and weather conditions on efficacy, selectivity and dissipation of herbicides in sunflower. Plant Soil Environ. 2020, 66, 468-476. [CrossRef]

13. Magomadov, A.; Avdeenko, A.P.; Avdeenko, S.S. The harmfulness of weeds in sunflower crops. AIP Conf. Proc. 2021, $2442,020004$. [CrossRef]

14. Pacanoski, Z.; Mehmeti, A. Weed control in sunflower (Helianthus annuus L.) with soil-applied herbicides affected by a prolonged and limited rainfall. Poljoprivreda 2021, 27, 3-14. [CrossRef]

15. Tan, S.; Evans, R.R.; Dahmer, M.L.; Singh, B.K.; Shaner, D.L. Imidazolinone-tolerant crops: History, current status and future. Pest. Manag. Sci. 2005, 61, 246-257. [CrossRef] [PubMed]

16. Tichý, L.; Jursík, M.; Kolářová, M.; Hejnák, V.; Andr, J.; Martinková, J. Sensitivity of sunflower cultivar PR63E82 to tribenuron and propaquizafop in different weather conditions. Plant Soil Environ. 2018, 64, 479-483. [CrossRef]

17. Arda, H.; Kaya, A.; Alyuruk, G. Physiological and genetic effects of imazamox treatment on imidazolinone-sensitive and resistant sunflower hybrids. Water Air Soil Pollut. 2020, 231, 118. [CrossRef]

18. Pardo, G.; Marí, A.I.; Aibar, J.; Vilaplana, L.; Cirujeda, A. Bastard cabbage (Rapistrum rugosum L.) resistance to tribenuron-methyl and iodosulfuron-methyl-sodium in Spain and alternative herbicides for its control. Agronomy 2019, 9, 492. [CrossRef]

19. Jat, R.; Giri, G. Influence of nitrogen and weed-control measures on weed growth, and seed and oil yields of sunflower (Helianthus annuus). Indian J. Agron. 2000, 45, 193-198.

20. Karkanis, A.; Athanasiadou, D.; Giannoulis, K.; Karanasou, K.; Zografos, S.; Souipas, S.; Bartzialis, D.; Danalatos, N. Johnsongrass (Sorghum halepense (L.) Pers.) Interference, control and recovery under different management practices and its effects on the grain yield and quality of maize crop. Agronomy 2020, 10, 266. [CrossRef]

21. Bradley, K.W.; Wu, J.; Hatzios, K.K.; Hagood, E.S., Jr. The mechanism of resistance to aryloxyphenoxypropionate and cyclohexanedione herbicides in a Johnsongrass biotype. Weed Sci. 2001, 49, 477-484. [CrossRef]

22. Scarabel, L.; Panozzo, S.; Savoia, W.; Sattin, M. Target-Site ACCase-resistant Johnsongrass (Sorghum halepense) selected in summer dicot crops. Weed Technol. 2014, 28, 307-315. [CrossRef]

23. Meyer, C.; Norsworthy, J.; Stephenson, D.; Bararpour, M.; Landry, R.; Woolam, B. Control of Johnsongrass in the absence of glyphosate in midsouth cotton production systems. Weed Technol. 2015, 29, 730-739. [CrossRef] 
24. Raul, C.; Stef, R.; Grozea, I. The cyclohexanediones effect on the Sorghum halepense control in the sunflower agroecosystem. Res. J. Agric. Sci. 2019, 51, 262-272.

25. Kanatas, P.; Antonopoulos, N.; Gazoulis, I.; Travlos, I.S. Screening glyphosate alternative weed control options in important perennial crops. Weed Sci. 2021, 69, 704-718. [CrossRef]

26. Griffin, J.L.; Miller, D.K.; Salassi, M.E. Johnsongrass (Sorghum halepense) control and economics of using glyphosate-resistant soybean in fallowed sugarcane fields. Weed Technol. 2006, 20, 980-985. [CrossRef]

27. Khan, R.U.; Morrison, I.N.; Rashid, A. Grass weed control in sunflower in the spring and kharif (summer) seasons under barani (rainfed) conditions in Pakistan. Crop Prot. 1988, 7, 9-15. [CrossRef]

28. Cobb, A.H.; Reade, J.P.H. Herbicides and Plant Physiology, 2nd ed.; John Wiley \& Sons Ltd.: Chichester, UK, 2010 ; pp. 1-285.

29. Incledon, B.J.; Hall, J.C. Acetyl-coenzyme A carboxylase: Quaternary structure and inhibition by graminicidal herbicides. Pestic. Biochem. Physiol. 1997, 57, 255-271. [CrossRef]

30. Pannacci, E.; Graziani, F.; Covarelli, G. Use of herbicide mixtures for pre and post-emergence weed control in sunflower (Helianthus annuus). Crop Prot. 2007, 26, 1150-1157. [CrossRef]

31. Wanjari, R.H.; Yaduraju, N.T.; Ahuja, K.N. Critical period of crop-weed competition in rainy-season sunflower (Helianthus annuus). Indian J. Agron. 2001, 46, 309-313.

32. Liava, V.; Karkanis, A.; Danalatos, N.; Tsiropoulos, N. Effects of two varieties and fertilization regimes on growth, fruit, and silymarin yield of milk thistle crop. Agronomy 2022, 12, 105. [CrossRef]

33. Simić, M.; Dragičević, V.; Knežević, S.; Radosavljević, M.; Dolijanović, Z.; Filipović, M. Effects of applied herbicides on crop productivity and on weed infestation in different growth stages of sunflower (Helianthus annuus L.). Helia 2011, 34, 27-38. [CrossRef]

34. Varalakshmi, K.; Neelima, S.; Narasimha Reddy, R.; Sreenivasulu, K.N. Genetic variability studies for yield and its component traits in newly developed sunflower (Helianthus annuus L.) hybrids. Electron. J. Plant Breed. 2020, 11, 301-305. [CrossRef]

35. Baghbani-Arani, A.; Jami, M.G.; Namdari, A.; Borz-Abad, R.K. Influence of irrigation regimes, zeolite, inorganic and organic manures on water use efficiency, soil fertility and yield of sunflower in a sandy soil. Commun. Soil Sci. Plant Anal. 2020, 51, 711-725. [CrossRef]

36. Pabuayon, I.L.B.; Singh, S.; Ritchie, G.L. Effects of deficit irrigation on yield and oil content of sesame, safflower, and sunflower. Agron. J. 2019, 111, 3091-3098. [CrossRef]

37. Hamzei, J.; Nasab, A.D.M.; Khoie, F.R.; Javanshir, A.; Moghaddam, M. Critical period of weed control in three winter oilseed rape (Brassica napus L.) cultivars. Turk. J. Agric. For. 2007, 31, 83-90. 